圈 ON HENRY MILLER 


\section{WRITERS ON WRITERS}

Philip Lopate Notes on Sontag

C. K. Williams On Whitman

Michael Dirda On Conan Doyle: Or, The Whole Art of Storytelling

Alexander McCall Smith What W. H. Auden Can Do for You

Colm Tóibín On Elizabeth Bishop

Michael Wood On Empson

John Burnside On Henry Miller: Or, How to Be an Anarchist 
JOHN BURNSIDE ON HENRY MILLER

Or, How to Be

an Anarchist

PRINCETON UNIVERSITY PRESS

Princeton and Oxford 
Copyright (C) 2018 by Princeton University Press

Published by Princeton University Press, 41 William Street, Princeton, New Jersey 08540

In the United Kingdom: Princeton University Press, 6 Oxford Street, Woodstock, Oxfordshire OX20 1TR

press.princeton.edu

Jacket photograph: Henry Miller (c) René Saint Paul / Bridgeman Images

Excerpt from the Tao Te Ching, trans. Derek Lin, from www.Taoism.net and Tao Te Ching: Annotated \& Explained, SkyLight Paths, 2006. Reprinted by permission.

Excerpt from "Carmel Point" by Robinson Jeffers, in The Collected Poems (Stanford University Press, 2002). Reprinted by permission of the Estate of Robinson Jeffers.

All Rights Reserved

ISBN 978-0-691-16687-2

Library of Congress Control Number: 2017961232

British Library Cataloging-in-Publication Data is available This book has been composed in Minion Pro and Myriad Pro Printed on acid-free paper. $\infty$

Printed in the United States of America

1098765543321 
for Phill Pass

- Be Well 
